\title{
Object Based Modelling for the Irrigation Suitability using Hydrogeochemical Parameters and Land use Dynamics in the Lower Ganga
}

Mohd Sayeed UI Hasan ( $\square$ sayeed.ce@aliah.ac.in )

Aliah University Faculty of Engineering https://orcid.org/0000-0002-5388-3383

Abhishek Kumar Rai

IIT Kharagpur: Indian Institute of Technology Kharagpur

\section{Research Article}

Keywords: ESA-CCI, GIS, GLDAS, Irrigation Suitability, TOPSIS

Posted Date: January 3rd, 2022

DOI: https://doi.org/10.21203/rs.3.rs-1054978/v1

License: (c) (i) This work is licensed under a Creative Commons Attribution 4.0 International License. Read Full License 


\section{Abstract}

The north Indian Ganga basin is one of the densely populated basins of the world. Most agricultural and industrial contaminants drained throughout the river length are likely to be accumulated in the lower part of the Ganga basin. We used ten derived irrigation suitability parameters, which are obtained from 495 sampling points locations, besides using long term climate data (GLDAS_NOAH025_M) using "Technique for Order of Preference by Similarity to Ideal Solution" (TOPSIS) model to get the irrigation suitability map. Multi-Criteria Decision Making (MCDM) using TOPSIS helps make the best choices from the available finite number of alternatives based on their ranking. The obtained entropy weight for irrigation suitability parameters such as Electrical Conductivity (Ec), Sodium Adsorption Ratio (SAR), Magnesium Hardness (MH), Sodium Percent (Na\%), Total Hardness (TH), Kelly's ratio (KR), Permeability Index (PI), Chloride concentration $\left(\mathrm{Cl}^{-}\right)$, Groundwater Level Fluctuation (GWLF), and lang factor (Df) are found to be $0.08,0.14,0.02,0.02,0.04,0.08,0.01,0.32,0.29$ and 0.01 respectively. We find that SAR, $\mathrm{Cl}^{-}$, and GWLF controls the water quality for irrigation in the Lower Ganga basin since these parameters have relatively higher entropy weights (more than 0.10). The results obtained from the computed performance index or the closeness coefficient show that the area percent having very good, good, and very poor groundwater quality in the Lower Ganga basin is $34.67 \%, 42.36 \%$, and $22.97 \%$, respectively. The LULC change pattern indicates that the percentage change of water and agricultural land was -11.96 and $-0.86 \%$, whereas an increase in the settlement area of $131.42 \%$ for the period between 2000 and 2015.

\section{Introduction}

Water is an essential natural resource vital for the sustainability of all life forms on the planet earth (Zia et al., 2013). Groundwater plays an important role for developing countries like India, as $70 \%$ of rural populations are dependent on agricultural productivity to sustain their livelihood. Due to rapid increase in population, groundwater demand also increases (Rodell et al.,2009; Bhanja et al.,2017). Groundwater shortage becomes one of the major challenges in India due to variability in rainfall and depletion of surface water. India's total population is approximately 1.24 billion, as per the 2011 census contributing to $17.80 \%$ of the global population (FAO,2013). The groundwater contributes about $53 \%$ of the total irrigation potential with about $50 \%$ of irrigated land depends upon the groundwater (CWC,2006; Nag and Das,2017) and helps in cultivating in the four seasons (Pre-monsoon, Monsoon, Post-monsoon, and Post-monsoon) of India. The estimated utilizable surface water, total replenishable groundwater resources, and groundwater resources available for irrigation are found to be $690 \mathrm{BCM}, 433 \mathrm{BCM}$, and 369.6 BCM, respectively (CWC,2007). In India, the agriculture sector utilizes approx. $89 \%$ of the total ground-water consumption (Mukherjee et al., 2015).

Highly contaminated groundwater can cause changes in soil penetrability, soil pH, soil structure, and supplement take-up by plants (Ayers and Westcot, 1985; Suarez et al.,2006; Iqbal et al., 2020). Study of the hydrogeochemistry of groundwater is essential because it can indicate about the groundwater quality for irrigation purpose, and proper planning and management for groundwater sustainable agricultural development which would enhance the agricultural productivity in a region. The groundwater quality deteriorates due to the use of chemicals, untreated factory discharge, and agricultural fertilizers used to enhance agricultural production. The point source contamination releases from the urban and industry in the form of wastewater, spills, leaks, runoff, and leachate are the factors responsible for the groundwater contamination. There are three main sources of groundwater contamination related with agricultural activity i.e. fertilizers (nitrate and phosphate), crop protections (pesticides and herbicides), and veterinary medicines (antibiotics) which reach into the groundwater through percolation (Burri et al., 2019). The quality of irrigation water directly affects soil and crops (Rahman et al., 2012).

A number of research paper have been published globally to identify the fate of groundwater contamination using artificial neural network (Wagh et al., 2016), multivariate statistics (Gharbi et al., 2019), fuzzy- TOPSIS (Kim et al.,2013), entropy method for agricultural land use (Hao et al.,2017), analytic hierarchy process (Okada et al.,2008), TOPSIS based on informative weight and ranking (Li et al., 2018). Peiyue et al., (2011) studied the drivers of hydrogeochemical evolution assessment and mechanisms of groundwater quality using the TOPSIS method for Pengyang county NW China and observed that the groundwater is fit for human consumption.

Integration of hydrogeochemical parameter of groundwater and Geographical Information System (GIS) plays an important role in determining the spatial distribution of various elements that affect the water quality and gives adequate information to the decision-makers for proper management and sustainable development of groundwater resources (Lasserre et al., 1999; Ni et al., 2010; Gnanachandrasamy et al., 2015; Venkatramanan et al., 2016; Elubid et al., 2019). MacDonald et al. 2016 studied the groundwater quality in the Indo-Gangetic Basin and observed the increase in the concentration of arsenic and salinity due to the highly variable nature of flow with depth. Integration of GIS and Multi-Criteria Decision making (MCDM) can act a tool for the decision-maker to ensure proper planning and management of groundwater for sustainable development (Joerin et al., 2001; Karnatak et al., 2007, Chen et al., 2010).

In this paper, integration of the entropy information weighted with Technique for Order of Preference by Similarity to Ideal Solution (TOPSIS) has been used in MCDM (Shanian and Savadogo, 2009; Park et al., 2011; Dammak et al.,2015; Dehdasht et al.,2020) for understanding the irrigation suitability of the groundwater in the Lower Ganga basin. Application of TOPSIS approach reduces the subjectivity in deciding the weight (Ewa, 
2011). Based on the selection criteria, the MCDM is classified into two classes i.e. Multiple Attribute Decision Making (MADM) and Multiple Object Decision Making (MODM). The difference between MADM and MODM is based on criteria, constrained, and alternatives. In MADM analysis criteria, constrained and alternative defined by attribute, inactive and finite number (discrete), whereas in MODM weights are assigned by objective, active, and infinite number (continuous) (Cohon,1978; Hwang et al.,1979).

Understanding changes in land use land cover (LULC) pattern also plays an important role for groundwater utilization plans. While environmental changes can influence surface water assets, changes in the major climatic factors, like air temperature, precipitation, and evapotranspiration, the impact of changing atmosphere factors on groundwater is difficult to evaluate (Jyrkama and Sykes, 2007). However, strong correlation has been observed between precipitation, temperature and groundwater levels (Fu et al., 2004). The study of land-use change dynamics is important because it helps in evaluating the interrelationship among various phenomenon based on Spatio-temporal analysis such as energy balance, food production, climate variability, and change, Ecohydrological process, amount of $\mathrm{CO}_{2}$ emission, surface and subsurface hydrological process, environmental monitoring and management, and also effects on hydrometeorological parameters (Fuchs et al., 2018; Li et al., 2018; Mousivand and Arsanjani, 2019).

Our study also focuses on seawater intrusion interaction using salinity index parameters like Ec, Na\%, SAR, etc. The results are relevant for planning and management of groundwater for irrigation scheduling besides crop designing pattern. The decision-maker should be aware and advice local population about the water treatment policy and implementation of irrigation policy to achieve sustainable groundwater management in the region.

\section{Study Area}

The lower Ganga basin is comprised of the north-east part of India having angular extension lies between $21^{\circ} 32^{\prime} 16^{\prime \prime} \mathrm{N}$ and $27^{\circ} 13^{\prime} 14^{\prime \prime} \mathrm{N}$, and $86^{\circ} 13^{\prime} 43^{\prime \prime} \mathrm{E}$, and $89^{\circ} 5^{\prime} 43^{\prime \prime} \mathrm{E}$ (Fig. 1). The altitudes of the study region vary from $-2 \mathrm{~m}$ and $3605 \mathrm{~m}$ (MSL), having at an average altitude of 80.72 $\mathrm{m}$ above mean sea level rise. The agribusiness is the primary financial endeavor of the Lower Ganga basin. The total area of the Lower Ganga basin consists of three administrative state boundaries, namely West Bengal, Bihar, and Jharkhand, with a total catchment area of 71613.18 $\mathrm{km}^{2}$. The estimated population as per the United Nation's World Population Prospects (UN-WPP) for the year 2020 obtained as 87462511 (CIESIN,2018). The soil texture of this region found the dominance of sandy clay loam, along with silty clay, clay responsible for the low infiltration into the subsurface. Four specific seasons are used for cropping namely early Kharif (black gram/urad), Kharif (rice, red gram), summer (pulses, green gram) and Rabi (Masur,gram).

\section{Data And Methodology}

A total 495 samples of hydrogeochemical parameters acquired from the Central Groundwater Board (CGWB), Government of India reports. These parameters include potential of hydrogen $(\mathrm{pH})$, electrical conductivity $(\mathrm{Ec})$, total dissolved solids (TDS), fluoride (F-), chloride (Cl-), bicarbonate (HCO3-), sulfate (SO42-), nitrate (NO3-), total hardness ( $\mathrm{TH})$, calcium (Ca2+), magnesium (Mg2+), sodium (Na+) and potassium $(\mathrm{K}+)$. The pre-monsoon data for the months of April-May 2016, samples have been collected from the bore well, dug well, and tube well from the

31 districts covering the study area. The methodology and collection of the hydrogeochemical data is consistent with standard conventions as per BIS 2012 standards. The derived irrigation parameter like Ec, SAR, $\mathrm{MH}, \% \mathrm{Na}, \mathrm{TH}, \mathrm{KR}, \mathrm{PI}, \mathrm{Cl}^{-}$, GWLF, and Df are used for the suitability mapping of the irrigation water quality. The complete methodology in this study are described in the following steps as (Fig. 2): (1) delineation of study area and sub-basin, (2) generation of raster data from point data, (3) selection of irrigation suitability criteria, (4) entropy weight calculation using normalization matrix, (5) prioritization of sub-basin using TOPSIS model, (6) land-use change dynamics.

The first and foremost part of the analysis is the delineation of the Lower Ganga basin using a published map by Water Resource Information System for the Ganga River (India-WRIS,2012). The georectification of the map was done into the GIS platform having the geographic coordinate system of WGS 1984 for further analysis. The SRTM DEM having a spatial resolution of 1-arc second ( 30m) was used for the drainage analysis for the sub-basin classification. Based on the drainage pattern characteristics, the Lower Ganga basin is classified into five sub-basins (Hasan \& Rai, 2020). The point data of the hydrogeochemical parameters are converted to raster surface using Inverse Distance Weightage Method (IDW) (Fig. 3). Further, the zonal statistics of each sub-basin for the prioritization of irrigation suitability using the TOPSIS method was done. For the study of irrigation suitability of groundwater, these parameters (SAR, MH, Na\%, KR, PI, Df) are computed using the following equations (Wilcox,1955; Todd,1959;Kelly,1963;Doneen,1964;Paiwal,1972;Brušková ,2007) (1-6) given below:

$$
\text { 1. Sodium Adsorption Ratio }(\mathrm{SAR})=\frac{\mathrm{Na}^{+}}{\sqrt{\left(\frac{\mathrm{Ca}^{2+}+M g^{2+}}{2}\right)}}(1)
$$


2. Magnesium Hardness $(\mathrm{MH})=\left(\frac{M g^{2+}}{C a^{2+}+M g^{2+}}\right) * 100(2)$

3. Percent Sodium $(\mathrm{Na} \%)=\left(\frac{\mathrm{Na}^{+}+\mathrm{K}^{+}}{\mathrm{Ca}^{2+}+\mathrm{Mg}^{2+}+\mathrm{K}^{+}+\mathrm{Na}^{+}}\right) * 100(3)$

4. Kelly's Ratio $(\mathrm{KR})=\left(\frac{N a^{+}}{\mathrm{Ca}^{2+}+M g^{2+}}\right)$ (4)

5. Permeability Index $(\mathrm{PI})=\frac{\left(\mathrm{Na}^{+}+\sqrt{\mathrm{HCO}_{3}^{-}}\right) * 100}{\left(\mathrm{Ca}^{2+}+\mathrm{Mg}^{2+}+\mathrm{Na}^{+}\right)}$(5)

6. Lang Factor (Df) $=P / T(6)$

Analysis of climate parameters using Lang factor (Df) helps to evaluate climatic regions based on groundwater uses (Brušková ,2007; Alwan et al., 2019). The $D f$ is defined as the ratio of the long term average annual precipitation $(P)$ in $\mathrm{mm}$ to the air temperature $(\mathrm{T})$ in ${ }^{\circ} \mathrm{C}$. The meteorological drought is the long term phenomenon caused due to the large lack of precipitation and higher evapotranspiration rate (Gregor,2013).

The long term precipitation and temperature data from 1948 to 2019 were obtained from the Global Land Data Assimilation System (GLDAS), having a spatial resolution of $0.25 * 0.25$ degree (Rodell et al., 2004). Both the precipitation and air temperature data are derived from the GLDAS_NOAH land surface model for the calculation of the lang factor. These data acts as the time average forcing field, which results from the remote sensing satellite data.

The Technique for Order Preference by Similarity to Ideal Solution (TOPSIS) model has been used since 1981 (Hwang and Yoon, 1981) in solving several types of multi-parametric decision-making problems. Hwang and Yoon give the details of the TOPSIS approach, helps to choose the best alternatives using the shortest Euclidean distance from the positive ideal solution, whereas the negative ideal solution having the farthest Euclidean distance showing the worst alternatives. For the application of TOPSIS, it must have decreasing or increasing nature, units incommensurable, and feature class must be numeric (Behzadian et al., 2012).

The following steps are involved in determining the TOPSIS model's entropy for the analysis of the irrigation quality of groundwater.

To study the spatial distribution of irrigation water quality for proper planning and management, the TOPSIS model has been applied using entropy weight defined in equation 3 to 8 . The first step for the TOPSIS is the non-linear ranking analysis, where the formation of the decision matrix " $X=(x i j) m * n$ " where $m=1,2,3, \ldots$. i, describes the alternatives showing sub-basin characteristics, whereas $n=1,2,3, \ldots . . j$, represents the quality parameter for the irrigation suitability. To remove the dataset's inconsistency in the system, the normalization of the matrix was done, which helps in forming the standardized decision matrix having a unit vector representing the magnitude and direction. The calculation of the relative weights of the parameter is based on Shannon's entropy information theory, which acts as the fuzziness of the parameter using the principle of probability and removes the biasness in the data (Shannon and Weaver, 1947; Zeleny, 1996; Wang and Lee, 2009). The formation of the ideal positive solution matrix based on the optimal value of the attribute, whereas the negative ideal solution obtained from the worst estimated entropy weight matrix. Important steps are as follows:

Step 1: Calculation of normalized decision matrix, $r_{i_{j}}$ and entropy, $e_{j}$ are defined as

$r_{i_{j}}=\frac{x_{i_{j}}}{\sum_{i=1}^{m} x_{i_{j}}}$ and $e_{j}=-\frac{1}{\ln (m)} \sum_{i=1}^{m} r_{i j} \ln \left(r_{i j}\right)(7)$

Step 2: Calculation of relative weights $\left(w_{j}\right)$ using Shannon's entropy information theory:

$$
w_{j}=\frac{1-e_{j}}{\sum_{j=1}^{n}\left(1-e_{j}\right)}
$$

8

Step 3: Calculation of positive $\left(v_{j}^{+}\right)$and negative $\left(v_{j}^{-}\right)$ideal solution 
$\left(v_{j}^{+}\right)=\max \left(v_{1 j}, v_{2 j}, v_{3 j} \ldots v_{m j}\right)$, and $\left(v_{j}^{-}\right)=\min \left(v_{1 j}, v_{2 j}, v_{3 j} \ldots v_{m j}\right)(9)$

Step 4: Calculation of the Euclidean distance of separation from each alternative to the positive $\left(S_{i}^{+}\right)$and negative $\left(S_{i}^{-}\right)$ideal solution

$S_{i}^{+}=\sqrt{\sum_{j=1}^{m}\left(V_{i j}-v_{i j}^{+}\right)^{2}}$ and $S_{i}^{-}=\sqrt{\sum_{j=1}^{m}\left(V_{i j}-V_{i j}^{-}\right)^{2}}(10)$

Step 5: Calculation of performance score or relative coefficient of closeness, $\mathrm{Pi}$

$$
P i=\frac{\left(S_{i}^{-}\right)}{\left(S_{i}^{+}+S_{i}^{-}\right)}
$$

11

One critical step in the TOPSIS technique is to compute the Euclidean distance of each parameter from the positive ideal best and negative ideal worst solution using equation 10. Finally, the performance index is derived using equation 11, which shows the relative closeness of each alternative based on the attribute parameter. The coefficient of relative closeness ranges from 0 to 1 . The performance score approaches to 1 represent the evaluation of criteria that are ideally close to the ideal positive solution, having better irrigation water quality (Gorgij et al., 2019). The ranking of the sub-basin is obtained based on the performance score as described above in descending order. The annual rate of land-use change ( $r$ ) over the period from T1 to T2 having the land use class area of A1 and A2 is expressed based on the compound interest law as given below (Puyravaud, 2003):

$\mathrm{R}=\ln (\mathrm{A} 2 / \mathrm{A} 1) /(\mathrm{T} 2-\mathrm{T} 1)(12)$

\section{Results And Discussion}

\section{Irrigation Suitability Parameter}

The evaluation of groundwater quality for irrigation suitability is important for enhancing agricultural productivity in the region. The richness of the soil depends upon the concentration of the dissolved ions in groundwater, which also affects the rate of infiltration, soil quality, and plant fertility, both physically and chemically (Ebong et al., 2017).

\section{Electrical Conductivity (Ec)}

The electrical conductivity EC is defined as the saline ionic concentration present in the groundwater in the form of maximum dissolved solids. An increase in the ionic concentration increases the EC of the water. Based on Ec values, the natural water is classified into eight classes (at 25 $\left.{ }^{\circ} \mathrm{C}\right)$ as ultra-pure water $(0.05-0.50 \mu \mathrm{S} / \mathrm{cm})$, distilled water $(1-10 \mu \mathrm{S} / \mathrm{cm})$, rainwater $(5-10 \mu \mathrm{S} / \mathrm{cm})$, potable water $(50-1000 \mu \mathrm{S} / \mathrm{cm})$, brackish water (2000-20,000 $\mu \mathrm{S} / \mathrm{cm})$, saline water (20,000-40,000 $\mu \mathrm{S} / \mathrm{cm})$, seawater $(40,000-60,000 \mu \mathrm{S} / \mathrm{cm})$ and brines $(>60,000 \mu \mathrm{S} / \mathrm{cm})($ Walton, 1989$)$. Excessive groundwater use in the coastal regions results in intrusion of seawater, leading to the deterioration of groundwater quality, thus increasing the salinity of the freshwater aquifer systems in the coastal areas (Pillay et al, 1994). Based on Ec, the groundwater is classified as excellent (<250 $\mu \mathrm{S} / \mathrm{cm})$, good $(250-750 \mu \mathrm{S} / \mathrm{cm})$, permissible $(750-2000 \mu \mathrm{S} / \mathrm{cm})$, doubtful $(2000-3000 \mu \mathrm{S} / \mathrm{cm})$, and unsuitable (>3000 $\mu \mathrm{S} / \mathrm{cm})$ for irrigation purpose (Richards,1954). We find that the electrical conductivity varies between $66.14 \mathrm{us} / \mathrm{cm}$ and $5278.59 \mu \mathrm{S} / \mathrm{cm}$ in the study area with a mean of $812.48 \mu \mathrm{S} / \mathrm{cm}$ (Fig. 3a). The mean value of Ec for Sub-basin $1(647.25 \mu \mathrm{S} / \mathrm{cm})$ and $2(576.92 \mu \mathrm{S} / \mathrm{cm})$ shows the good quality of groundwater. In contrast, sub-basin $3(864.23 \mu \mathrm{S} / \mathrm{cm})$, sub-basin $4(779.51 \mu \mathrm{S} / \mathrm{cm})$, and sub-basin $5(1182.92 \mu \mathrm{S} / \mathrm{cm})$ shows the permissible limit (Richards,1954). The higher concentration of Ec along the shoreline is due to the intermixing of freshwater and saline water by seawater intrusion. The detailed variation of Ec for each of the sub-basins is given in Fig. 4a. The high value of Ec shows, higher concentration of the salinity level in groundwater. The presence of salt into the groundwater helps in plant growth. Still, the excess concentration will lead to deteriorating the soil fertility and decreases permeability and aeration, which can affect crop germination and agricultural productivity. The major causes of increased salinity could be the weathering and leaching of rocks, seawater intrusion, excess evapotranspiration, discharge of untreated industrial waste, and excessive use of fertilizers in agricultural activities.

\section{Sodium Adsorption Ratio (SAR)}

SAR indicates the influence of sodium ion concentration concerning the calcium and magnesium ions present in the groundwater and its interactions with the soil. SAR plays a crucial role in understanding the quality of the water used for agricultural purposes. It determines the 
impact of a high concentration of sodium ion in groundwater on agricultural productivity (Bhunia et al., 2018). High salinity decreases the osmotic activity and affects soil productivity because an increase in sodium will decrease the concentration of calcium and magnesium ions in the soil (Subramani et al., 2005; Prasanth et al., 2012). A higher concentration of sodium ions causes the alkalinity in the soil (Singh et al., 2011). For irrigation purposes, the groundwater can be categorized into four classes based on SAR i.e. excellent (<10 meq/I), good (10-18 meq/l), doubtful (18-26 meq/l), and unsuitable (>26 meq/l) (Richards,1954; Todd,1980). The spatial variation of SAR in the study region is found to be between $0.08 \mathrm{meq} / \mathrm{l}$ and $17.61 \mathrm{meq} / \mathrm{l}$ with a mean value of $2.28 \mathrm{meq} / \mathrm{l}(1 \sigma= \pm 1.78)$. The computed mean value of SAR (Fig. $3 \mathrm{~b}$ ) of individual sub-basin found to be below $10 \mathrm{meq} / \mathrm{l}$, which shows excellent condition for irrigation suitability. SAR results show that this type of groundwater for all types of soil taking care of excessive concentration of $\mathrm{Na}+$ ions. The descriptive statistics and guidelines for SAR are given in Table 6.

\section{Magnesium Hardness (MH) or Magnesium Adsorption Ratio (MAR)}

MH was developed by Paliwal in 1972 using $\mathrm{Ca}^{2+}$ and $\mathrm{Mg}^{2+}$ for studying irrigation water quality and helps in achieving groundwater equilibrium mostly (Hem, 1985). It is found that $\mathrm{Ca}^{2+}$ and $\mathrm{Mg}^{2+}$ help in maintaining the equilibrium in water (Paliwal, 1972;Giggenbach, 1988). Paliwal (1972), classified groundwater into two groups based on $\mathrm{MH}$ i.e. suitable $(\mathrm{MH}<50)$ and unsuitable $(\mathrm{MH}>50)$. We find that the $\mathrm{MH}$ values range between $0.06 \mathrm{meq} / \mathrm{l}$ and $90.84 \mathrm{meq} / \mathrm{l}$ in the study areas, with a mean value of $45.81 \mathrm{meq} / \mathrm{l}(1 \sigma=13.34)$ (Fig. 3c). Fig. $4 \mathrm{a}$ clearly shows that the mean value of all the sub-basin lies within $50 \mathrm{meq} / \mathrm{l}$ except sub-basin $2(54.32 \mathrm{meq} / \mathrm{I})$. The lower value of MAR ( $<50 \mathrm{meq} / \mathrm{I})$ is favourable for crop yield. Thus, the sub-basin 2 have a high concentration of $\mathrm{MH}(>50 \mathrm{meq} / \mathrm{l})$, which will affect the agricultural productivity of the crop and increases the alkalinity of the soil in the study area.

\section{Sodium Percent (Na\%) or Sodium Hazard or Soluble Sodium Percentage (SSP)}

$\mathrm{Na} \%$ is an essential parameter for the irrigation water classification. The soil water interaction of sodium ion reduces the permeability of soil (Nag and Das, 2017). The sodium percent is calculated the relative ratio of cations $\mathrm{Na}^{+}$and $\mathrm{K}^{+}$with respect to $\mathrm{Ca}^{2+}, \mathrm{Mg}^{2+}, \mathrm{Na}^{+}$, and $\mathrm{K}^{+}$present in the groundwater sample (Wilcox, 1955; Raghunath, 1987). Depending upon the ionic concentration (Na\%), the groundwater is classified into five categories: excellent (<20), good (20-40), permissible (40-60), doubtful (60-80), and unsuitable (>80) for irrigation suitability (Wilcox,1955). Higher the value of $\mathrm{Na} \%$ means water quality is not appropriate for irrigation, which causes soil permeability to be deflocculated and impaired. For this study, the sodium percent varies from 4.93 and $92.27 \mathrm{meq} / \mathrm{l}$, with a mean value of $41.44 \mathrm{meq} / \mathrm{l}(1 \sigma=13.59)$, showing favorable conditions for groundwater irrigation in the Lower Ganga basin (Fig. 3d). Results show that the mean value of individual sub-basin 1 (39.79meq/I), 3 (34.51meq/I), and 4 (37.42meq/I) are under the good category. In comparison, sub-basin 2 (43.05meq/I) and 5 (48.74meq/I) fall under the permissible limit as per the classification given by Wilcox in 1955 (Fig. 4a).

\section{Total Hardness (TH)}

TH of the samples in the study area lies between $1.19 \mathrm{mg} / \mathrm{l}$ and $1134.31 \mathrm{mg} / \mathrm{l}$ having a mean value of $223.15 \mathrm{mg} / \mathrm{I}(1 \sigma=80.26), \mathrm{greater}$ than $300 \mathrm{mg} / \mathrm{l}$, which shows the quality of groundwater is unsuitable for irrigation (Fig. 3e). As per the classification is given by Sawyer and McCartly in 1967, irrigation groundwater classifies into four classes as soft (<75 mg/l), moderate (75-150 mg/l), hard (150-300 mg/l), and very hard (>300 $\mathrm{mg} / \mathrm{l})$. The mean value of the spatial distribution of TH in the study area falls between $150-300 \mathrm{mg} / \mathrm{l}$ for all the five sub-basin, which suggests a hard quality of groundwater for the Lower Ganga basin (Fig. 4a).

\section{Kelly's Ratio (KR)}

KR is also an important parameter for the analysis of groundwater quality (Kelly, 1963), and is defined as the concentration of sodium ion over $\mathrm{Ca}^{2+}$ and $\mathrm{Mg}^{2+}$. The higher value of $\mathrm{KR}$ reduces soil fertility because it increases the concentration of $\mathrm{Na}^{+}$ion concentration into the soil. Based on $\mathrm{KR}$, the groundwater for irrigation are classified into two categories as suitable $(\mathrm{KR}<1)$, and unsuitable $(\mathrm{KR}>1)(\mathrm{Kelly}, 1963)$. The overall concentration of $\mathrm{KR}$ in the study area varies from $0.05 \mathrm{meq} / \mathrm{l}$ to $11.84 \mathrm{meq} / \mathrm{l}$, with a mean value of $0.79 \mathrm{meq} / \mathrm{l}(1 \sigma=0.66)$ in the study region (Fig. 3f). Results show that all the sub-basins are under suitable conditions for irrigation, except sub-basin-5 which has KR value of 1.12 meq/l, which is higher than the recommended value. This indicates unsuitable groundwater for irrigation water quality (Fig. $4 \mathrm{~b}$ ).

\section{Permeability Index (PI)}

Another important parameter to understand the water quality for irrigation purposes is PI. Doneen (1964) classify irrigation water quality based on $\mathrm{PI}$ into three categories: good $(\mathrm{PI}<80)$, moderate $(80<\mathrm{Pl}<100)$, and poor $(\mathrm{PI}>100)$ based on the concentration of $\mathrm{Na}^{+}, \mathrm{HCO}_{3}{ }^{-}, \mathrm{Ca}^{2+}, \mathrm{and}^{2+}$ into the soil. Results show that the PI values of the groundwater samples in the study areas range from $26.41 \mathrm{meq} / \mathrm{I}$ to $170.21 \mathrm{meq} / \mathrm{I}$ with a mean value of $67.92 \mathrm{meq} / \mathrm{l}(1 \sigma=13.11)$ (Fig. $3 \mathrm{~g})$. The mean value of PI in the study area is below 80 which indicates that the quality of soil is not much affected by long term irrigation in the area. PI values of all sub-basins fall lies below $80 \mathrm{meq} / \mathrm{l}$, which indicates the good quality of groundwater for irrigation suitability shown in Fig. 4b. 


\section{Chloride Concentration (meq/l)}

The presence of Chloride in the groundwater acts as a fundamental micronutrient as a cofactor in the oxidation of water in photosynthesis and also acts as an enzyme activator in the crops (Kafkafi, 2011). The anion concentration of chloride is stable and helps maintain the balance among cation ions of $\mathrm{Na}^{+}, \mathrm{K}^{+}, \mathrm{Ca}^{2+}$, and $\mathrm{Mg}^{2+}$ in the soil. Mass (1990) defines the impacts of chloride (meq/l) concentration into the groundwater for the agricultural productivity classified as safe for all type of plants $\left(\mathrm{Cl}^{-}<2.03\right)$, sensitive plants experienced damage $\left(2.03<\mathrm{Cl}^{-}<4.06\right)$, Plants which are moderately tolerant show injury $\left(4.07<\mathrm{Cl}^{-}<10.15\right)$, and $\mathrm{Cl}^{-}>10.15$ causes a severe effect on crops (Mass,1990). As $\mathrm{Cl}^{-}$is not absorbed by soils, and flows through transpiration and in the leaves, it accumulates, which causes necrosis and early leaf defoliation (Ayers and Wetcot,1994; Ogunfowokan et al., 2013). The obtained $\mathrm{Cl}^{-}$ionic concentration lies in the range between $0.13 \mathrm{meq} / \mathrm{l}$ to $36.45 \mathrm{meq} / \mathrm{l}$ with a mean value of $3.79 \mathrm{meq} / \mathrm{l}$ (Fig. 3h). Sub-basin 2 has the mean $\mathrm{Cl}^{-}$concentration of $1.82 \mathrm{meq} / \mathrm{l}$ showing safe for all types of plants. On the other hand, the sub-basin $2(2.56 \mathrm{meq} / \mathrm{l})$, sub-basin $3(2.15 \mathrm{meq} / \mathrm{l})$, and sub-basin $4(3.59 \mathrm{meq} / \mathrm{l})$ are under-sensitive zone which may cause infertility to crops due to prolonged presence of $\mathrm{Cl}^{-}$into the groundwater (Fig. $4 \mathrm{~b}$ ). The mean value of sub-basin 5 obtained to be $7.19 \mathrm{meq} / \mathrm{l}$, which higher than all the other four sub-basin due to the presence of high concentration salinity in this region. The interaction of freshwater and seawater takes by seawater intrusion to have a large number of stream confluences in the lower part of the study area.

\section{Groundwater Level Fluctuation (GWLF)}

The ground-based well data of groundwater levels collected by CGWB across India in four seasons (Rabi, Pre-Monsoon, Monsoon, PostMonsoon, Kharif) from the Water Resource Information System (WRIS) archives of the year 2016 having pre-monsoon and post-monsoon data for the understanding the groundwater level fluctuation in the study area. The data were converted into raster format using geostatistical interpolation by applying inverse distance weighted (IDW) method. The water level depends upon the amount of precipitation, topography, land use type, hydrogeology, and hydrological soil group of the region. In the Lower Ganga basin, groundwater is used for irrigation. The premonsoon groundwater level varies from $0.41 \mathrm{~m}$ to $27.79 \mathrm{~m}$, having the mean value to $6.85 \mathrm{~m}$. Most of the aquifer in this region is recharge due to the monsoon rainfall, which subsequently decreases the groundwater level. The observed post-monsoon minimum, maximum, and mean groundwater level from the well locations heads in this region found at $0.30 \mathrm{~m}, 22.03 \mathrm{~m}$, and $4.96 \mathrm{~m}$, respectively. The decline in groundwater level is basically due to the excessive pumping of groundwater for irrigation purposes used for the crop. The groundwater level fluctuation varies from $-14.12 \mathrm{~m}$ and $24.18 \mathrm{~m}$ with a mean value of $1.90 \mathrm{~m}$ in the Lower Ganga basin (Fig. 3i). The decreasing order of mean groundwater fluctuation found in sub-basin $1(4.19 \mathrm{~m})$, sub-basin $3(2.86 \mathrm{~m})$, sub-basin $4(1.80 \mathrm{~m})$, sub-basin $2(1.76 \mathrm{~m})$ and sub-basin $5(0.84 \mathrm{~m})$ (Fig. $4 \mathrm{~b})$. The higher fluctuation represents the unstable groundwater, whereas less fluctuation shows the static groundwater condition, which further stays in the dry period in the study area.

\section{Lang factor (Df)}

Analysis of the climate parameters using Lang factor (Df) helps in evaluating climatic regions based on groundwater uses (Brušková ,2007; Alwan et al., 2019). The long term climatic regions are classified on the basis of Lang factor are described as: dry region ( $\mathrm{Df}<60)$, relatively dry $(60<D f<70)$, transient $(70<D f<80)$, wet $(80<D f<100)$, and very wet $(D f>100)$ determined by using hydroclimatic parameters such as precipitation and air temperature (Brušková ,2007; Gregor,2012). The Df value in the Lower Ganga basin varies from 52.40 to 94.08 , with a mean value over the temporal scale of 71 years found to be 63.15 (Fig. 3j). The results show that the average region of the Lower Ganga basin is under relatively dry conditions. Sub-basin 3 (53.02) and sub-basin 4 (58.47) have a significant dry condition and proper irrigation scheduling required over this region. Sub-basin 2 (67.70) and sub-basin 5 (65.77) have dry conditions, whereas sub-basin 1 having mean values of Df is 72.02 represents the area having transition phase (Fig. 4b). The lower value of Df responsible for a decline in groundwater recharge, whereas higher Df values help in getting a good amount of available groundwater resources for irrigation purposes (Alwan et al., 2019).

For the assessment of irrigation water quality, the following criteria are included such as $\mathrm{Ec}, \mathrm{SAR}, \mathrm{MH}, \mathrm{Na} \%, \mathrm{TH}, \mathrm{KR}, \mathrm{PI}, \mathrm{Cl}^{-}, \mathrm{GWLF}$, and $\mathrm{Df}$ are used in this study area. The five alternatives (sub-basins) and ten parameters used for the normalization matrix using equation 7, help in standardization of the datasets. The entropy of each parameter was computed to determine randomness for irrigation suitability. The entropy for Ec, SAR, MH, Na\%, TH, KR, PI, Cl- , GWLF and Df are found to be $0.98,0.96,1.00,1.00,0.99,0.98,1.00,0.91,0.92$ and, 1.0 respectively (Table 2). Shannon's entropy technique assigns weights in an unbiased way for the Multi-Criteria Decision Making (MCDM). The computed relative weights of each criterion help in indicating the potential towards the groundwater deterioration concerning irrigation suitability. Using equation 8, the computed relative weights of Ec, SAR, MH, Na\%, TH, KR, PI, Cl', GWLF and Df are obtained as $0.08,0.14,0.02,0.02,0.04,0.08,0.01,0.32,0.29$, and 0.01 respectively (Table 2). The relative weight of the TOPSIS model lies between 0 to 1 , and the summation of all weights is equal to one (Hasan \& Rai, 2020).

The highest entropy weight is obtained from $\mathrm{Cl}^{-}(0.32), \operatorname{GWLF}(0.29)$, and SAR (0.14), higher than 0.10 , and acts as the primary role in determining the irrigation quality of the study area. The entropy weight of other parameters such as $\mathrm{Ec}(0.08), \mathrm{MH}(0.02), \mathrm{Na} \%(0.02), \mathrm{TH}(0.04)$, 
KR (0.08), PI (0.01), and Df (0.01) was found to be less than 0.10 which shows these parameters are of secondary importance in assessing irrigation suitability of groundwater quality.

Determination of a positive ideal solution helps in maximizing the benefits and minimizing the cost (Table 3 ). In contrast, a negative ideal solution maximizes cost and minimizes the benefit in selecting alternatives (Table 4). Higher the value of the performance index or coefficient of closeness means closer the separation distance from the ideal positive best solution, and farther from the negative ideal worst solution using Euclidean distances (Mohapatra \& Patnaik, 2013), as shown in Tables 8 and 9. Therefore, it is important to keep in mind for hydrophysical quality analysis, the fate of the concentration should be taken into consideration. The classification of TOPSIS based on the coefficient of performance index $(\mathrm{Pi})$ as very good $(0.75<\mathrm{Pi}<1.00)$, good $(0.50<\mathrm{Pi}<0.75)$, moderate $(0.25<\mathrm{Pi}<0.50)$, poor $(0.125<\mathrm{Pi}<0.50)$, and very poor $(0<\mathrm{Pi}<0.125)$ (Bagherzadeh and Gholizadeh, 2016).

The Euclidean distance of the separation helps in the selection of the best and worst criteria alternatives depending upon the degree of relative closeness. Therefore, the selection of the alternatives depends upon the highest relative closeness from the ideal positive solution.

As per the TOPSIS model applied in the Lower Ganga basin for irrigation suitability mapping, the obtained performance index or the coefficient of the closeness of sub-basin 1 (0.91) and sub-basin $2(0.97)$ showing higher values means very good quality of groundwater available for the irrigation purpose. On the other hand, compared to sub-basin $3(0.60)$ and sub-basin $4(0.70)$, it has good groundwater quality for irrigation. The results also show that the sub-basin 5 (0.07) showing the performance index minimum of all sub-basin, indicating very poor quality of groundwater for irrigation purposes (Table 5).

The irrigation water quality of the upper northern region has a very good groundwater quality for irrigation due to the accumulation of soil nutrients coming from the river stream. Therefore, these regions having agricultural productivity very high. The very poor quality of sub-basin 5 having Pi value 0.07 indicate the presence of seawater intrusion along the coastline of the landmass with the Bay of Bengal and reduces the agricultural productivity of this region. The Geovisualization of the TOPSIS model and the results that we obtained are shown in Fig. 5.

\section{Spatio-temporal Analysis Of Land Use Dynamics}

The global annual land cover map provided by the European Space Agency (ESA) is in association with the Climate Change Initiative (CCI) produced from 1992 till now (Mousivand \& Arsanjani, 2019). The weighted overall accuracy of the ESA CCI land cover map is 73\% having the sample datasets of 3167 (Defourny et al., 2009). The annual ESA CCI land cover map is resampled at 300m spatial resolution having the GCS coordinate using World Geodetic System 84 (WGS84). The land use dataset from European Space Agency (ESA) under Climate Change Initiative (CCI) used having the total number land cover (LC) classes 22, defined as per the United Nation (UN) Land Cover Classification System (LCCS) developed by Food and Agriculture Organization (FAO), based on the Plant Function Type (PFT) for the wide application in various models (Di Gregorio, 2005; CCI-LC,2011). For our study, the 22 classes are recoded to reduce into six types defined by IPCC classification, i.e., agriculture, forest, grassland, wetland, settlement, and other (shrubland, sparse vegetation, bare area, and water).

Land-use change pattern over the period from 2000,2005,2010, and 2015 was studied to determine the of land-use conversion from one class to another. Land use/land cover in the study region is shown in Fig. 6 and also in Table 6 for the period of 2000 to 2015 at an interval of five years. The change detection (transformation matrix) was prepared from 2000 to 2015, showing the amount of conversion of land use from one class to another. The land use classification and area in $\mathrm{km}^{2}$ are shown in Table 7. Results show that there is a decline in the percentage of land use class of forest $(-2.13 \%)$, grassland $(-26.22 \%)$, shrubland $(-1.87 \%)$, sparse vegetation $(-0.47 \%)$, and water $(-2.20 \%)$, without any substantial change in agricultural land use from 2000 to 2005 . With an increase in the land-use class of wetland (20.95\%), settlement (39.23\%), and a significant increase in bare area (151.92\%) having the percentage population change of $8.18 \%$ throughout $2000-2005$. We observed that the six classes of land use show a positive increase in the forest (0.64\%), grassland (10.91\%), wetland (5.03\%), settlement (24.02\%), sparse vegetation (1.43\%), and bare area (100.76\%), with a decrease in three classes of agriculture $(-0.31 \%)$, shrubland $(-5.82 \%)$, and water $(-1.15 \%)$ having the percentage of population change of $7.11 \%$ over the period from 2005 to 2010 shown in Fig. 7. It is also noted that the maximum loss of agriculture class $(-0.56 \%)$ takes place during the period of 2010 to 2015 with a considerable increase in forest area (1.14\%) and also showing a minimum percentage of the population of $6.02 \%$. Similarly, there is a significant increase in the percentage of grassland (5.24\%), settlement (34.02\%), sparse vegetation (0.47\%), and bare area (37.64\%) in the Lower Ganga basin (Fig. 7).

The land use transformation matrix helps in evaluating the trajectory of land-use patterns over the spatiotemporal scale. As the determination of land-use change dynamics suggests in determining the environmental changes and sustainable development in the study area. The land-use transition matrix helps understand the shift in land use class "from-to" another class over a period of time using remote sensing data (Jensen,2005; Teferi, Bewket, Uhlenbrook, \& Wenninger, 2013). The row of the cross-tabulation matrix (transition matrix) represents the initial period T1, i.e.,2000 and column represents the final time T2, i.e.,2015 of land-use class, and the diagonal of the transition matrix represents the persistent land-use class having constant area. The transition matrix for the land-use class having a persistent area of agriculture, forest, grassland, wetland, settlement, shrubland, sparse vegetation, bare area, and water is found to be $61552.71 \mathrm{~km} 2,3882.33 \mathrm{~km} 2,104.22 \mathrm{~km} 2$, 
$12.96 \mathrm{~km} 2,570.51 \mathrm{~km} 2,63.72 \mathrm{~km} 2,37.53 \mathrm{~km} 2,3.15 \mathrm{~km} 2$, and $4135.95 \mathrm{~km} 2$, respectively Over the period from 2000 to 2015 . From the analysis, it is found that agriculture has a decreasing tendency from 2000 to 2015 with a net change of $539.1 \mathrm{~km} 2$, which is converted into other land-use classes. The table, , $_{\text {, }}$ shows that spatial conversion of agricultural land contributes from $101.16 \mathrm{~km} 2,74.61 \mathrm{~km} 2,3.87 \mathrm{~km} 2,0.18 \mathrm{~km} 2,0.45 \mathrm{~km} 2$, $67.68 \mathrm{~km} 2$ to the forest, grassland, shrubland, sparse vegetation, bare area, and water, respectively. The forest area is also showing a negative net change of $15.48 \mathrm{~km} 2$ from $4018.32 \mathrm{~km} 2$ to $4002.84 \mathrm{~km} 2$ from 2000 to 2015 . Grassland depicts the net change of $-26.55 \mathrm{~km} 2$ from 191.16 $\mathrm{km} 2$ to $164.61 \mathrm{~km} 2$. The transformation of wetland does not show any significant change over the 15 years, with an increase of $3.6 \mathrm{~km} 2$. Interestingly, there is a substantial increase in the settlement area from $570.51 \mathrm{~km}^{2}$ to $1320.3 \mathrm{~km}^{2}$, with a net increase of $749.79 \mathrm{~km} 2$ from 2000 2015. The amount of land-use conversion from another class to settlement takes place from agriculture $\left(705.42 \mathrm{~km}^{2}\right)$, forest $\left(16.2 \mathrm{~km}^{2}\right)$, grassland $\left(2.07 \mathrm{~km}^{2}\right)$, shrubland $\left(0.54 \mathrm{~km}^{2}\right)$, sparse vegetation $\left(0.36 \mathrm{~km}^{2}\right)$, and water bodies $\left(25.2 \mathrm{~km}^{2}\right)$. There is no conversion from wetland and bare area to the settlement over a period of 15 years. There is a decreasing trend in the shrubland with a net change of $-9.81 \mathrm{~km} 2 \mathrm{from}$ $81.99 \mathrm{~km}^{2}$ to $72.18 \mathrm{~km}^{2}$ in the Lower Ganga basin. The bare area converted from $4.68 \mathrm{~km} 2$ in 2000 to $32.58 \mathrm{~km} 2$ in 2015 , with a considerable increase of $27.9 \mathrm{~km}^{2}$ area. The availability of water in any region determines the livelihood and agricultural pattern of the region. It is observed that a significant change in the water bodies occurs over the period of analysis. A net decline of water bodies area of $-190.89 \mathrm{~km}^{2}$ is observed from $4355.37 \mathrm{~km}^{2}$ to $4164.48 \mathrm{~km}^{2}$ in the Lower Ganga basin. The water bodies are converted into the following other land-use class as agriculture $\left(8.64 \mathrm{~km}^{2}\right)$, forest $\left(8.91 \mathrm{~km}^{2}\right)$, grassland $\left(9.63 \mathrm{~km}^{2}\right)$, wetland $\left(0.27 \mathrm{~km}^{2}\right)$, bare area $\left(1.08 \mathrm{~km}^{2}\right)$ over the period of 15 years. The percentage rate of land-use class change varies from -1-12.94\% from 2000 to 2015.

As the land use, land cover change explains the impact of anthropogenic activities with respect to the natural system. Currently, there are not many places on earth where the expansion of arable land is feasible, and it almost always comes with a high environmental cost at the same time.

\section{Conclusion}

In this paper, we applied TOPSIS model approach to understand the suitability of groundwater for irrigation purpose in the Lower Ganga, and also focused on the understanding the land-use dynamics in this region. Analysis of ten water quality parameters from 495 sampling points, reveals that three parameters, namely SAR (0.14), $\mathrm{Cl}^{-}(0.32)$, and GWLF (0.29), show significant role in controlling the irrigation water quality as they are highly dependent on the hydrogeological and hydrometeorological conditions. Results show that sub-basin 1 and 2 have very good, sub-basin 3 and 4 having good quality, and sub-basin 5 having very poor quality of groundwater for irrigation. The percentage area having very good, good, and very poor irrigation water quality is $34.67 \%, 42.36 \%$, and $22.97 \%$, respectively. The study of land-use dynamics shows that there is a significant change in the bare area, settlement area, and wetland area with an increasing percentage of $596.15 \%, 131.42 \%$, and $27.03 \%$, respectively between 2000 to 2015 . It is also seen that there is a decrease in the percentage area of agriculture (-0.86\%), forest (-0.39\%), grassland (-13.89\%), shrubland (-11.96\%), and water (-4.38\%) with the total population increase of $22.85 \%$ in the Lower Ganga basin between 2000 and 2015.

It is a matter of concern that there is a decrease in the agricultural land area, which is obtained as $923.01 \mathrm{~m}^{2} / \mathrm{person}$ in the year 2000 , with available agriculture land of $744.86 \mathrm{~m}^{2} /$ person in the year 2015 . Therefore, results are highly important for the policymakers and local authorities who are to take preventive measure against the groundwater quality deterioration and food security. Results are extremely useful to achieve the United Nations Sustainable Development Goal (UN-SDG) to accomplish the agenda in 2030.

\section{Declarations}

\section{Conflict of interest:}

The authors declare, they have no conflict of interest.

\section{Funding Statement:}

No external funding received.

\section{Author's Contribution:}

Mohd Sayeed UI Hasan: Methodology; Formal analysis; Investigation; Visualization; Writing - original draft

Abhishek Kumar Rai: Supervision; Conceptualization; Project administration; Resources; Writing - Review \& Editing

\section{Availability of data and material:}

The data used in this manuscript are available on their respective website and free available. 
Code Availability: No code applicable.

Ethics Approval: We confirm that this work is original and has not been published elsewhere, nor is it currently under consideration for publication elsewhere.

Consent to participate and publication: The author's willingly to participate in the publication of the above manuscript.

\section{Acknowledgements}

The authors would gratefully acknowledge to the IIT Khragpur and Aliah University, for providing all the resources. The author also sincerely acknowledges the CGWB, ESA-CCI and GLDAS for providing the datasets used in this work.

\section{References}

1. Alwan, I.A., Karim, H.H., Aziz, N.A., 2019. Groundwater Aquifer Suitability for Irrigation Purposes Using Multi-Criteria Decision Approach in Salah Al-Din Governorate/Iraq. AgriEngineering 1, 303-323. https://doi.org/10.3390/agriengineering1020023

2. Ayers, R.S., Westcot, D.W., 1985. Water quality for agriculture. FAO Irrigation and Drainage Paper 29 Rev 1. FAO, UN, Rome, pp. 174.

3. Bagherzadeh A., Gholizadeh A., 2016. Modeling land suitability evaluation for wheat production by parametric and TOPSIS approaches using GIS, northeast of Iran. Model. Earth Syst. Environ. 2, 126 https://doi.org/10.1007/s40808-016-0177-8

4. Behzadian, M., Khanmohammadi Otaghsara, S., Yazdani, M., Ignatius, J., 2012. A state-of the-art survey of TOPSIS applications. Expert Syst. Appl. 39, 13051-13069. https://doi.org/10.1016/j.eswa.2012.05.056

5. Bhanja, S.N., Malakar, P., Mukherjee, A., Rodell, M., Mitra, P., Sarkar, S., 2019. Using Satellite-Based Vegetation Cover as Indicator of Groundwater Storage in Natural Vegetation Areas. Geophys. Res. Lett. 46, 8082-8092. https://doi.org/10.1029/2019GL083015

6. Bhunia, G.S., Keshavarzi, A., Shit, P.K., Omran, E.-S.E., Bagherzadeh, A., 2018. Evaluation of groundwater quality and its suitability for drinking and irrigation using GIS and geostatistics techniques in semiarid region of Neyshabur, Iran. Appl. Water Sci. 8, 168. https://doi.org/10.1007/s13201-018-0795-6

7. Brušková V. 2007. Hodnotenie meteorologického sucha v povodí horného toku Torysy. [In Slovak with English abstract and summary] (Evaluation of meteorological drought in the upper part of Torysa catchment). Podzemná voda 13(2):169-176, SAH, Bratislava

8. Burri, N.M., Weatherl, R., Moeck, C., Schirmer, M., 2019. A review of threats to groundwater quality in the anthropocene. Sci. Total Environ. 684, 136-154. https://doi.org/10.1016/j.scitotenv.2019.05.236

9. Center for International Earth Science Information Network (CIESIN), 2018. Columbia University. Documentation for the Gridded Population of the World, Version 4 (GPWv4), Revision 11 Data Sets. Palisades NY: NASA Socioeconomic Data and Applications Center (SEDAC). https://doi.org/10.7927/H45Q4T5F

10. Central Water Commission (CWC)., 2006. Water and related statistics. Central Water Commission, Ministry of Water Resources, Government of India, New Delhi

11. Central Water Commission (CWC)., 2007. Annual Report, Central Water Commission, Ministry of Water Resources, Government of India, New Delhi

12. Chaudhary, V., Satheeshkumar, S., 2018. Assessment of groundwater quality for drinking and irrigation purposes in arid areas of Rajasthan, India. Appl. Water Sci. 8, 1-17. https://doi.org/10.1007/s13201-018-0865-9

13. Chen, Y., Yu, J., Khan, S., 2010. Spatial sensitivity analysis of multi-criteria weights in GIS-based land suitability evaluation. Environ. Model. Softw. 25, 1582-1591. https://doi.org/10.1016/j.envsoft.2010.06.001

14. Cohon, J.L., 1978. Multi Objective Programming and Planning. Academic Press, New York.

15. Dammak, F., Baccour, L., Alimi, A.M., 2015. The impact of criterion weights techniques in TOPSIS method of multi-criteria decision making in crisp and intuitionistic fuzzy domains. IEEE Int. Conf. Fuzzy Syst. 2015-Novem, 1-8. https://doi.org/10.1109/FUZZ-IEEE.2015.7338116

16. Defourny, P., Schouten, L., Bartalev, S., Bontemps, S., Caccetta, P., De Wit, A.J.W., Di Bella, C., Gérard, B., Giri, C., Gond, V., Hazeu, G.W., Heinimann, A., Herold, M., Knoops, J., Jaffrain, G., Latifovic, R., Lin, H., Mayaux, P., Mücher, C.A., Nonguierma, A., Stibig, H.J., Van Bogaert, E., Vancutsem, C., Bicheron, P., Leroy, M., Arino, O., 2009. Accuracy assessment of a $300 \mathrm{~m}$ global land cover map: The GlobCover experience. Proceedings, 33rd Int. Symp. Remote Sens. Environ. ISRSE 2009 400-403.

17. Dehdasht, G., Salim Ferwati, M., Zin, R.M., Abidin, N.Z., 2020. A hybrid approach using entropy and TOPSIS to select key drivers for a successful and sustainable lean construction implementation, PLoS ONE. https://doi.org/10.1371/journal.pone.0228746

18. Doneen L.D., 1964. Water Quality for Agriculture, Department of Irrigation, University of Calfornia, Davis, pp. 48.

19. Ebong, E.D., Akpan, A.E., Emeka, C.N., Urang, J.G., 2017. Groundwater quality assessment using geoelectrical and geochemical approaches: case study of Abi area, southeastern Nigeria. Appl. Water Sci. 7, 2463-2478. https://doi.org/10.1007/s13201-016-0439-7 
20. Elubid, B.A., Huag, T., Ahmed, E.H., Zhao, J., Elhag, K.M., Abbass, W., Babiker, M.M., 2019. Geospatial distributions of groundwater quality in Gedaref state using geographic information system (GIS) and drinking water quality index (DWQI). Int. J. Environ. Res. Public Health 16, 120. https://doi.org/10.3390/ijerph16050731

21. Ewa, R., 2011. Multi-Criteria Decision Making Models By Applying the Topsis Method To Crisp and Interval Data. Mult. Criteria Decis. Making/University Econ. Katowice 6, 200-230.

22. Food and Agriculture Organization of the United Nations (FAO), 2013. FAO statistical yearbook 2013. Rome, Italy: World Food and Agriculture, 289.

23. Fu, G., Chen, S., Liu, C., Shepard, D., 2004. Hydro-climatic trends of the yellow river basin for the last 50 years. Clim. Change $65,149-178$. https://doi.org/10.1023/B: CLIM.0000037491.95395.bb

24. Fuchs, R., Prestele, R., Verburg, P.H., 2018. A global assessment of gross and net land change dynamics for current conditions and future scenarios. Earth Syst. Dyn. 9, 441-458. https://doi.org/10.5194/esd-9-441-2018

25. Gharbi, A., Ali, Z.I., Zairi, M., 2019. Groundwater suitability for drinking and agriculture purposes using irrigation water quality index and multivariate analysis: case of Sidi Bouzid aquifer, central Tunisia. Environ. Earth Sci. 78, 1-19. https://doi.org/10.1007/s12665-019-8733-y

26. Giggenbach W.F., 1988. Geothermal solute equilibria, derivation of Na-K-Mg-Ca geoindicators. Geochim Cosmochim Acta 52(12):27492765

27. Gnanachandrasamy, G., Ramkumar, T., Venkatramanan, S., Vasudevan, S., Chung, S.Y., Bagyaraj, M., 2015. Accessing groundwater quality in lower part of Nagapattina district, Southern India: using hydrogeochemistry and GIS interpolation techniques. Appl. Water Sci. 5, 39-55. https://doi.org/10.1007/s13201-014-0172-z

28. Gorgij, A.D., Wu, J., Moghadam, A.A., 2019. Groundwater quality ranking using the improved entropy TOPSIS method: a case study in Azarshahr plain aquifer, east Azerbaijan, Iran. Hum. Ecol. Risk Assess. 25, 176-190. https://doi.org/10.1080/10807039.2018.1564235

29. Gregor, M., 2013. Surface-and Groundwater Quality Changes in Periods of Water Scarcity; Springer Science \& Business Media: Bratislava, Slovakia https://doi.org/10.1007/978-3-642-32244-0

30. Hao, L., Su, X., Singh, V.P., Ayantobo, O.O., 2017. Spatial optimization of agricultural land use based on cross-entropy method. Entropy 19. https://doi.org/10.3390/e19110592

31. Hem, J.D., 1985. Study and Interpretation the Chemical of Natural of Characteristics Water. USGS Sci. a Chang. world 272.

32. Hwang, C.L., Masud, A.S.M., 1979. “Multiple Objective Decision Making: Methods and Applications: A State-Of- The-Art Survey," Lecture Notes in Economics and Mathematical Systems, vol. 164. Springer-Verlag, Berlin, Heidelberg. https:// doi.org/10.1007/978-3-642-45511-7.

33. Hwang, C.-L., Yoon, K., 1981. Lecture Notes in Econmoics and Mathematical Systems.

34. India-WRIS, 2012. River Basin Atlas of India. Jodhpur: RRSC-West, NRSC, ISRO.

35. Iqbal, A.B., Rahman, M.M., Mondal, D.R., Khandaker, N.R., Khan, H.M., Ahsan, G.U., Jakariya, M., Hossain, M.M., 2020. Assessment of Bangladesh groundwater for drinking and irrigation using weighted overlay analysis. Groundw. Sustain. Dev. 10, 100312. https://doi.org/10.1016/j.gsd.2019.100312

36. Jensen, J.R., 2005. Introductory Digital Image Processing: A Remote Sensing Perspec- tive. Prentice Hall, Upper Saddle River, NY.

37. Joerin, F., Theriault, M., Musy, A., 2001. Using GIS and outranking multicriteria analysis for land-use suitability assessment. International Journal of Geographical Information Science 15 (2), $153 \mathrm{e} 174$.

38. Jyrkama, M.I., Sykes, J.F., 2007. The impact of climate change on spatially varying groundwater recharge in the grand river watershed (Ontario). J. Hydrol. 338, 237-250. https://doi.org/10.1016/j.jhydrol.2007.02.036

39. Kafkafi, U., 2011. Effects of chlorides in effluents used for irrigation on the irrigated crops. Isr. J. Plant Sci. 59, $139-146$. https://doi.org/10.1560/IJPS.59.2-4.139

40. Karnatak, H.C., Saran, S., Bhatia, K., Roy, P.S., 2007. Multicriteria spatial decision analysis in web GIS environment. Geoinformatica 11, 407 e429.

41. Kelly W. P., 1963. Use of saline irrigation water. Soil Science, 95, 355-391.

42. Kim, Y., Chung, E.S., Jun, S.M., Kim, S.U., 2013. Prioritizing the best sites for treated wastewater instream use in an urban watershed using fuzzy TOPSIS. Resour. Conserv. Recycl. 73, 23-32. https://doi.org/10.1016/j.resconrec.2012.12.009

43. Lasserre, F., Razack, M., Banton, O., 1999. A GIS-linked model for the assessment of nitrate contamination in groundwater. J. Hydrol. 224, 81-90. https://doi.org/10.1016/S0022-1694(99)00130-4

44. Li, W., Macbean, N., Ciais, P., Defourny, P., Lamarche, C., Bontemps, S., Houghton, R.A., Peng, S., 2018. Gross and net land cover changes in the main plant functional types derived from the annual ESA CCI land cover maps (1992-2015). Earth Syst. Sci. Data 10, $219-234$. https://doi.org/10.5194/essd-10-219-2018 
45. Li, Z., Yang, T., Huang, C.S., Xu, C.Y., Shao, Q., Shi, P., Wang, X., Cui, T., 2018. An improved approach for water quality evaluation: TOPSISbased informative weighting and ranking (TIWR) approach. Ecol. Indic. 89, 356-364. https://doi.org/10.1016/j.ecolind.2018.02.014

46. MacDonald, A.M., Bonsor, H.C., Ahmed, K.M., Burgess, W.G., Basharat, M., Calow, R.C., Dixit, A., Foster, S.S.D., Gopal, K., Lapworth, D.J., Lark, R.M., Moench, M., Mukherjee, A., Rao, M.S., Shamsudduha, M., Smith, L., Taylor, R.G., Tucker, J., Van Steenbergen, F., Yadav, S.K., 2016. Groundwater quality and depletion in the Indo-Gangetic Basin mapped from in situ observations. Nat. Geosci. 9, 762-766. https://doi.org/10.1038/ngeo2791

47. Mass., 1990. Crop salt tolerance. Agricultural salinity assessment and management manual. In: Tanji KK (ed) ASCE, New York, pp 262-304

48. Mousivand, A., Arsanjani, J.J., 2019. Insights on the historical and emerging global land cover changes: The case of ESA-CCI-LC datasets. Appl. Geogr. 106, 82-92. https://doi.org/10.1016/j.apgeog.2019.03.010

49. Mukherjee, A., Saha, D., Harvey, C.F., Taylor, R.G., Ahmed, K.M., Bhanja, S.N., 2015. Groundwater systems of the Indian Sub-Continent. J. Hydrol. Reg. Stud. 4, 1-14. https://doi.org/10.1016/j.ejrh.2015.03.005

50. Nag, S.K., Das, S., 2017. Assessment of groundwater quality from Bankura I and II Blocks, Bankura District, West Bengal, India. Appl. Water Sci. 7, 2787-2802. https://doi.org/10.1007/s13201-017-0530-8

51. Ni, F.Q., Liu, G.D., Tan, Y.S., Deng, Y., 2010. Spatial variation of health risk of groundwater for drinking water supply in Mingshan County, Ya'an City, China. Water Sci. Eng. 3, 454-466. https://doi.org/10.3882/j.issn.1674-2370.2010.04.008

52. Ogunfowokan, A.O., Obisanya, J.F., Ogunkoya, O.O., 2013. Salinity and sodium hazards of three streams of different agricultural land use systems in Ile-Ife, Nigeria. Appl. Water Sci. 3, 19-28. https://doi.org/10.1007/s13201-012-0053-2

53. Okada, H., Styles, S.W., Grismer, M.E., 2008. Application of the Analytic Hierarchy Process to irrigation project improvement. Part I. Impacts of irrigation project internal processes on crop yields. Agric. Water Manag. 95, 199-204. https://doi.org/10.1016/j.agwat.2007.10.003

54. Paliwal, K.V., 1972. Irrigation with Saline Water. Water Technology Centre, Indian Agriculture Research Institute, New Delhi, 198 p.

55. Park, J.H., Park, I.Y., Kwun, Y.C., Tan, X., 2011. Extension of the TOPSIS method for decision making problems under interval-valued intuitionistic fuzzy environment. Appl. Math. Model. 35, 2544-2556. https://doi.org/10.1016/j.apm.2010.11.025

56. Peiyue, L.I., Hui, Q., Jianhua, W.U., 2011. Hydrochemical Formation Mechanisms and Quality Assessment of Groundwater with Improved TOPSIS Method in Pengyang County Northwest China.

57. Pillay, M.S., Selim, M.I., Siru, D., 1994. Drinking-water quality monitoring and surveillance. Waterlines $13,8-10$. https://doi.org/10.3362/0262-8104.1994.037

58. Puyravaud, J.P., 2003. Standardizing the calculation of the annual rate of deforestation. For. Ecol. Manage. $177,593-596$. https://doi.org/10.1016/S0378-1127(02)00335-3

59. Raghunath, H.M., 1987. Groundwater. Wiley Eastern Ltd., Delhi

60. Richards L.A., 1954. Diagnosis and improvement of saline and alkali soils. US department of agriculture, Handbook, $p$ 60

61. Rodell, M., Houser, P.R., Jambor, U., Gottschalck, J., Mitchell, K., Meng, C.-J., Arsenault, K., Cosgrove, B., Radakovich, J., Bosilovich, M., Entin, J.K., Walker, J.P., Lohmann, D., Toll, D., 2004. The Global Land Data Assimilation System. Bull. Am. Meteorol. Soc. 85, $381-394$. https://doi.org/10.1175/BAMS-85-3-381

62. Rodell, M., Velicogna, I., Famiglietti, J.S., 2009. Satellite-based estimates of groundwater depletion in India. Nature 460, $999-1002$. https://doi.org/10.1038/nature08238

63. Sarath Prasanth, S. V., Magesh, N.S., Jitheshlal, K. V., Chandrasekar, N., Gangadhar, K., 2012. Evaluation of groundwater quality and its suitability for drinking and agricultural use in the coastal stretch of Alappuzha District, Kerala, India. Appl. Water Sci. 2, $165-175$. https://doi.org/10.1007/s13201-012-0042-5

64. Sawyer C.N., McCarty P.L., 1967. Chemistry of sanitary engineers, 2nd edn. McGraw Hill, New York, p 518

65. Sayeed, M., Hasan, U., Rai, A.K., 2020. Groundwater quality assessment in the Lower Ganga Basin using entropy information theory and GIS. J. Clean. Prod. 274, 123077. https://doi.org/10.1016/j.jclepro.2020.123077

66. Shanian, A., Savadogo, O., 2009. A methodological concept for material selection of highly sensitive components based on multiple criteria decision analysis. Expert Syst. Appl. 36, 1362-1370. https://doi.org/10.1016/j.eswa.2007.11.052

67. Shannon, C.E., Weaver, W., 1947. The Mathematical Theory of Communication. The University of Illinois Press, Urbana.

68. Singh, A.K., Tewary, B.K., Sinha, A., 2011. Hydrochemistry and Quality Assessment of Groundwater in Part of NOIDA Metropolitan City, Uttar Pradesh, Journal Geological Society of India.

69. Suarez, D.L., Wood, J.D., Lesch, S.M., 2006. Effect of SAR on water infiltration under a sequential rain-irrigation management system. Agric. Water Manag. 86 (1-2), 150-164. https://doi.org/10.1016/j.agwat.2006.07.010.

70. Subramani, T., Elango, L., Damodarasamy, S.R., 2005. Groundwater quality and its suitability for drinking and agricultural use in Chithar River Basin, Tamil Nadu, India. Environ. Geol. 47, 1099-1110. https://doi.org/10.1007/s00254-005-1243-0

Page 12/21 
71. Tanvir Rahman, M.A.T.M., Rahman, S.H., Majumder, R.K., 2012. Groundwater quality for irrigation of deep aquifer in southwestern zone of Bangladesh. Songklanakarin J. Sci. Technol. 34, 345-352.

72. Teferi, E., Bewket, W., Uhlenbrook, S., Wenninger, J., 2013. Understanding recent land use and land cover dynamics in the source region of the Upper Blue Nile, Ethiopia: Spatially explicit statistical modeling of systematic transitions. Agric. Ecosyst. Environ. 165, 98-117. https://doi.org/10.1016/j.agee.2012.11.007

73. Todd, D.K. 1980. Groundwater hydrology. John Wiley and Sons Inc., New York, U.S.A., pp. 10-138.

74. Venkatramanan, S., Chung, S.Y., Ramkumar, T., Rajesh, R., Gnanachandrasamy, G., 2016. Assessment of groundwater quality using GIS and CCME WQI techniques: a case study of Thiruthuraipoondi city in Cauvery deltaic region, Tamil Nadu, India. Desalin. Water Treat. 57, 1205812073. https://doi.org/10.1080/19443994.2015.1048740

75. Wagh, V.M., Panaskar, D.B., Muley, A.A., Mukate, S.V., Lolage, Y.P., Aamalawar, M.L., 2016. Prediction of groundwater suitability for irrigation using artificial neural network model: a case study of Nanded tehsil, Maharashtra, India. Model. Earth Syst. Environ. 2, 1-10. https://doi.org/10.1007/s40808-016-0250-3

76. Walton, N.R.G., 1989. Electrical Conductivity and Total Dissolved Solids-What is Their Precise Relationship? Desalination 72, $275-292$. https://doi.org/10.1016/0011-9164(89)80012-8

77. Wang, T.C., Lee, H. Da, 2009. Developing a fuzzy TOPSIS approach based on sub- jective weights and objective weights. Expert Syst. Appl. 36, 8980e8985. https://doi.org/10.1016/j.eswa.2008.11.035.

78. Wilcox, L. V., 1955. Classification and use of irrigation water. Agric. Circ. No. 969,Washington, DC USDA. 1-19. https://doi.org/USDA Circular No. 969.

79. Zeleny, M., 1996. Multiple Criteria Decision Making. Springer, New York.

80. Zia, H., Harris, N.R., Merrett, G. V, Rivers, M., Coles, N., 2013. The impact of agricultural activities on water quality: A case for collaborative catchment-scale management using integrated wireless sensor networks. Comput. Electron. Agric. 96, 126-138.

https://doi.org/10.1016/j.compag.2013.05.001

\section{Tables}

Table 1: Dimensionless normalization matrix for decision

\begin{tabular}{|lllllllllll|}
\hline Sub-Basin & Ec & SAR & MH & $\% \mathrm{Na}$ & $\mathrm{TH}$ & $\mathrm{KR}$ & $\mathrm{PI}$ & $\mathrm{Cl}$ & GWLF & Df \\
\hline 1 & 0.16 & 0.17 & 0.20 & 0.20 & 0.19 & 0.19 & 0.19 & 0.15 & 0.37 & 0.23 \\
\hline 2 & 0.14 & 0.17 & 0.24 & 0.21 & 0.14 & 0.21 & 0.23 & 0.11 & 0.15 & 0.21 \\
\hline 3 & 0.21 & 0.14 & 0.20 & 0.17 & 0.21 & 0.14 & 0.18 & 0.12 & 0.25 & 0.17 \\
\hline 5 & 0.19 & 0.17 & 0.20 & 0.18 & 0.21 & 0.16 & 0.19 & 0.21 & 0.16 & 0.18 \\
\hline & 0.29 & 0.35 & 0.17 & 0.24 & 0.25 & 0.30 & 0.21 & 0.42 & 0.07 & 0.21 \\
\hline
\end{tabular}

Table 2: Computation of entropy and weight

\begin{tabular}{lllllllllll} 
Sub-Basin & Ec & SAR & MH & $\% \mathrm{Na}$ & $\mathrm{TH}$ & $\mathrm{KR}$ & $\mathrm{PI}$ & $\mathrm{Cl}$ & $\mathrm{GWLF}$ & Df \\
\hline 1 & -0.29 & -0.30 & -0.32 & -0.32 & -0.32 & -0.31 & -0.32 & -0.28 & -0.37 & -0.34 \\
\hline 2 & -0.28 & -0.30 & -0.34 & -0.33 & -0.28 & -0.33 & -0.34 & -0.24 & -0.29 & -0.33 \\
\hline 3 & -0.33 & -0.27 & -0.32 & -0.30 & -0.33 & -0.28 & -0.31 & -0.26 & -0.35 & -0.30 \\
\hline 4 & -0.32 & -0.30 & -0.32 & -0.31 & -0.33 & -0.30 & -0.32 & -0.33 & -0.29 & -0.31 \\
\hline 5 & -0.36 & -0.37 & -0.30 & -0.34 & -0.35 & -0.36 & -0.33 & -0.36 & -0.19 & -0.33 \\
\hline Total & -1.58 & -1.55 & -1.60 & -1.60 & -1.59 & -1.57 & -1.61 & -1.47 & -1.48 & -1.60 \\
\hline ej & 0.98 & 0.96 & 1.00 & 1.00 & 0.99 & 0.98 & 1.00 & 0.91 & 0.92 & 1.00 \\
\hline 1-ej & 0.02 & 0.04 & 0.00 & 0.00 & 0.01 & 0.02 & 0.00 & 0.09 & 0.08 & 0.00 \\
\hline wj & 0.08 & 0.14 & 0.02 & 0.02 & 0.04 & 0.08 & 0.01 & 0.32 & 0.29 & 0.01
\end{tabular}

Table 3: Positive ideal best solution 


\begin{tabular}{lllllllllll} 
Sub-Basin & Ec & SAR & $\mathrm{MH}$ & $\% \mathrm{Na}$ & $\mathrm{TH}$ & $\mathrm{KR}$ & $\mathrm{PI}$ & $\mathrm{Cl}$ & GWLF & Df \\
\hline 1 & 3.82 & 0.00 & 0.00 & 0.00 & 0.65 & 0.00 & 0.00 & 0.01 & 0.32 & 0.00 \\
\hline 2 & 0.00 & 0.00 & 0.02 & 0.00 & 0.00 & 0.00 & 0.01 & 0.00 & 0.00 & 0.60 \\
\hline 3 & 88.31 & 0.00 & 0.00 & 0.00 & 1.23 & 0.00 & 0.00 & 0.00 & 0.62 & 9.04 \\
\hline 4 & 38.90 & 0.00 & 0.00 & 0.00 & 1.22 & 0.00 & 0.00 & 0.12 & 0.33 & 5.10 \\
\hline 5 & 585.82 & 0.03 & 0.00 & 0.01 & 4.50 & 0.00 & 0.00 & 3.08 & 0.10 & 1.22
\end{tabular}

Table 4: Negative ideal worst solution

\begin{tabular}{lllllllllll} 
Sub-Basin & Ec & SAR & $\mathrm{MH}$ & $\% \mathrm{Na}$ & $\mathrm{TH}$ & $\mathrm{KR}$ & $\mathrm{PI}$ & $\mathrm{Cl}$ & $\mathrm{GWLF}$ & $\mathrm{Df}$ \\
\hline 1 & 495.05 & 0.03 & 0.01 & 0.01 & 1.73 & 0.00 & 0.00 & 2.69 & 0.05 & 9.04 \\
\hline 2 & 585.82 & 0.03 & 0.00 & 0.00 & 4.50 & 0.00 & 0.00 & 3.08 & 0.62 & 4.97 \\
\hline 3 & 219.23 & 0.03 & 0.01 & 0.01 & 1.02 & 0.00 & 0.01 & 2.92 & 0.00 & 0.00 \\
\hline 4 & 322.81 & 0.03 & 0.01 & 0.01 & 1.04 & 0.00 & 0.00 & 1.99 & 0.04 & 0.56 \\
\hline 5 & 0.00 & 0.00 & 0.02 & 0.00 & 0.00 & 0.00 & 0.00 & 0.00 & 0.22 & 3.62
\end{tabular}

Table 5: Calculation of performance score or Coefficient of closeness (Pi)

\begin{tabular}{llllll} 
Sub-Basin & $\mathrm{S}^{-}$ & $\mathrm{S}^{+}$ & $\mathrm{Pi}$ & Class & \% Area \\
\hline 1 & 22.55 & 2.19 & 0.91 & Very Good & 11.29 \\
\hline 2 & 24.47 & 0.79 & 0.97 & Very Good & 23.38 \\
\hline 3 & 14.94 & 9.96 & 0.60 & Good & 5.29 \\
\hline 4 & 18.07 & 6.76 & 0.73 & Good & 37.07 \\
\hline 5 & 1.96 & 24.39 & 0.07 & Very poor & 22.97
\end{tabular}

Table 6: Spatiotemporal percentage change of land use and population from 2000-2015

\begin{tabular}{lllll} 
Land Use & \%Change 2000-2005 & \%Change 2005-2010 & \%Change 2010-2015 & \%Change 2000-2015 \\
Class & & & & -0.86 \\
\hline Agriculture & 0.00 & -0.31 & -0.56 & -0.39 \\
\hline Forest & -2.13 & 0.64 & 1.14 & -13.89 \\
\hline Grassland & -26.22 & 10.91 & 5.24 & 27.03 \\
\hline Wetland & 20.95 & 5.03 & 0.00 & 131.42 \\
\hline Settlement & 39.23 & 24.02 & 34.02 & -11.96 \\
\hline Shrub land & -1.87 & -5.82 & -4.75 & 1.42 \\
\hline Sparse Vegetation & -0.47 & 1.43 & 0.47 & 596.15 \\
\hline Bare Area & 151.92 & 100.76 & 37.64 & -4.38 \\
\hline Water & -2.20 & -1.15 & -1.10 & 22.85
\end{tabular}

Table 7: Land Use Transition Matrix between 2000 to 2015 


\begin{tabular}{|c|c|c|c|c|c|c|c|c|c|c|}
\hline $\begin{array}{l}\text { Land Use } \\
\text { Class }\end{array}$ & Agriculture & Forest & Grassland & Wetland & Settlement & $\begin{array}{l}\text { Shrub } \\
\text { land }\end{array}$ & $\begin{array}{l}\text { Sparse } \\
\text { Vegetation }\end{array}$ & $\begin{array}{l}\text { Bare } \\
\text { Area }\end{array}$ & Water & Total 2015 \\
\hline Agriculture & 61552.71 & 101.16 & 74.61 & 0 & 0 & 3.87 & 0.18 & 0.45 & 67.68 & 61800.66 \\
\hline Forest & 42.84 & 3882.33 & 0 & 0.09 & 0 & 13.86 & 0 & 0 & 63.72 & 4002.84 \\
\hline Grassland & 13.59 & 0 & 104.22 & 0 & 0 & 0 & 0 & 0 & 46.8 & 164.61 \\
\hline Wetland & 0 & 1.62 & 0 & 12.96 & 0 & 0 & 0 & 0 & 2.34 & 16.92 \\
\hline Settlement & 705.42 & 16.2 & 2.07 & 0 & 570.51 & 0.54 & 0.36 & 0 & 25.2 & 1320.3 \\
\hline Shrubland & 0.36 & 8.1 & 0 & 0 & 0 & 63.72 & 0 & 0 & 0 & 72.18 \\
\hline $\begin{array}{l}\text { Sparse } \\
\text { Vegetation }\end{array}$ & 0.36 & 0 & 0 & 0 & 0 & 0 & 37.53 & 0 & 0.72 & 38.61 \\
\hline Bare Area & 15.84 & 0 & 0.63 & 0 & 0 & 0 & 0 & 3.15 & 12.96 & 32.58 \\
\hline Water & 8.64 & 8.91 & 9.63 & 0.27 & 0 & 0 & 0 & 1.08 & 4135.95 & 4164.48 \\
\hline Total 2000 & 62339.76 & 4018.32 & 191.16 & 13.32 & 570.51 & 81.99 & 38.07 & 4.68 & 4355.37 & 71613.18 \\
\hline
\end{tabular}

Figures

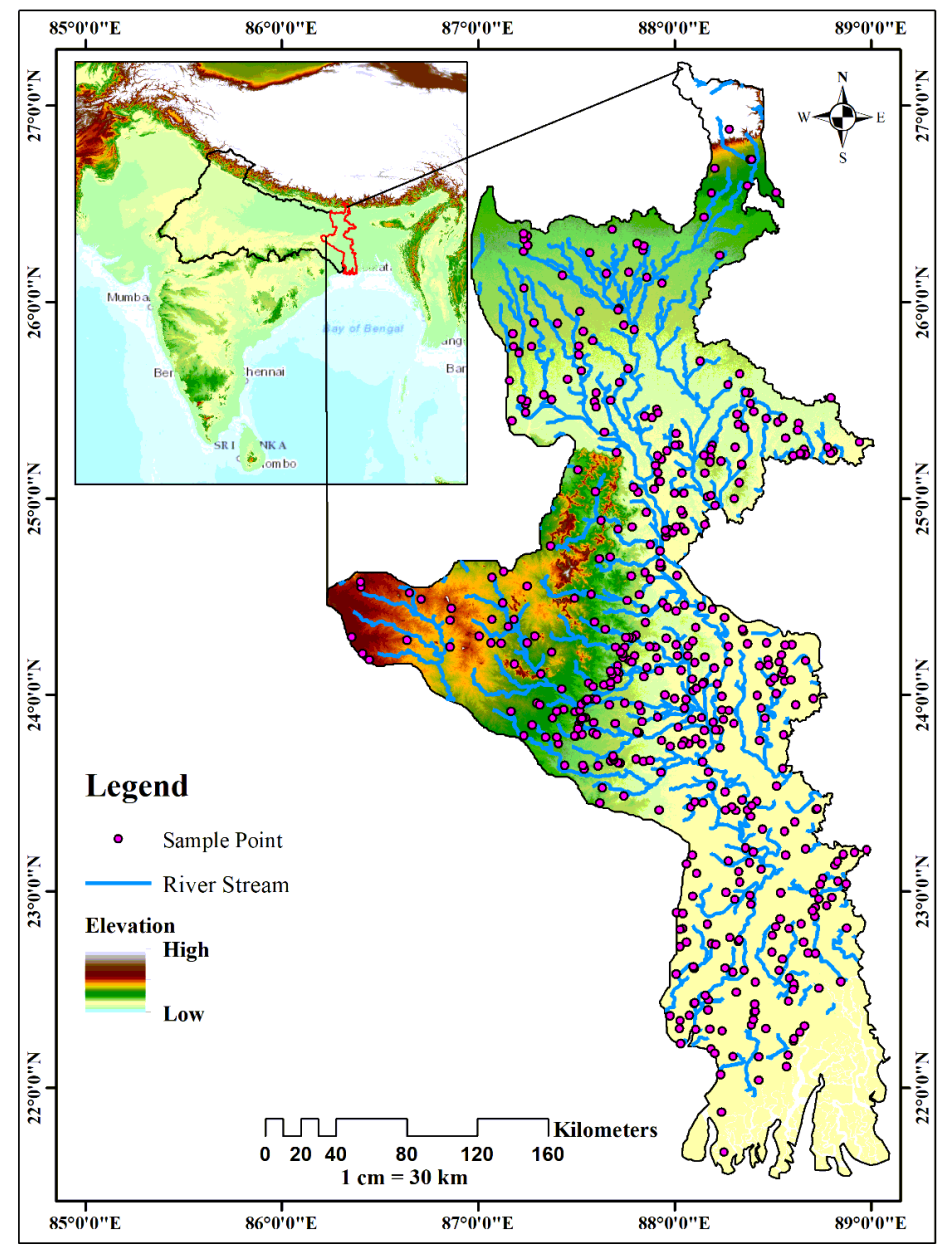

Figure 1 


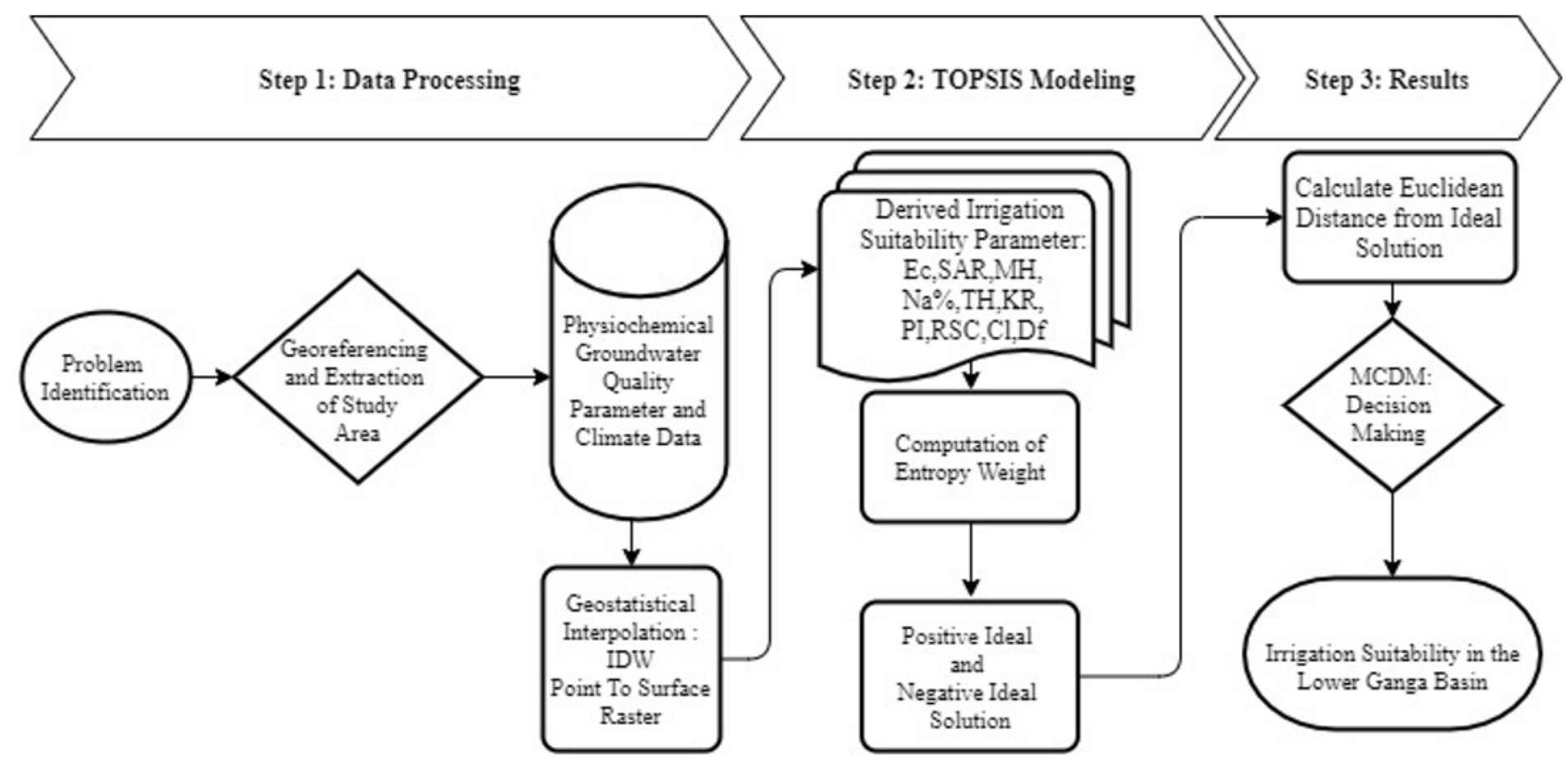

\section{Figure 2}

Flowchart showing the TOPSIS Model for irrigation suitability 


\begin{tabular}{|c|}
\hline 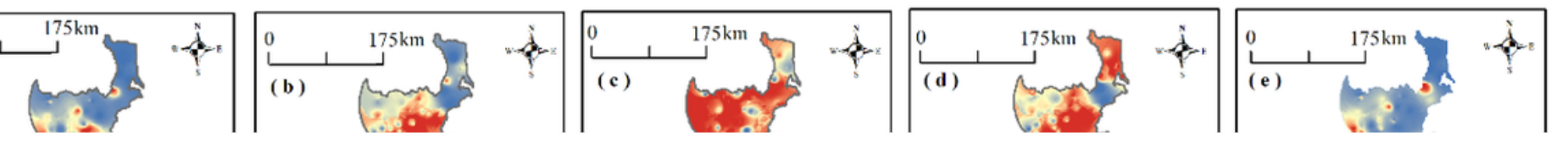 \\
\hline
\end{tabular}

\section{Figure 3}

Geovisualization of irrigation suitability parameter- (a) Ec (b)SAR (c) MH (d) Na \%€ TH (f) KR (g) PI (h) Chloride (i) Groundwater level fluctuation (j) Lang factor 


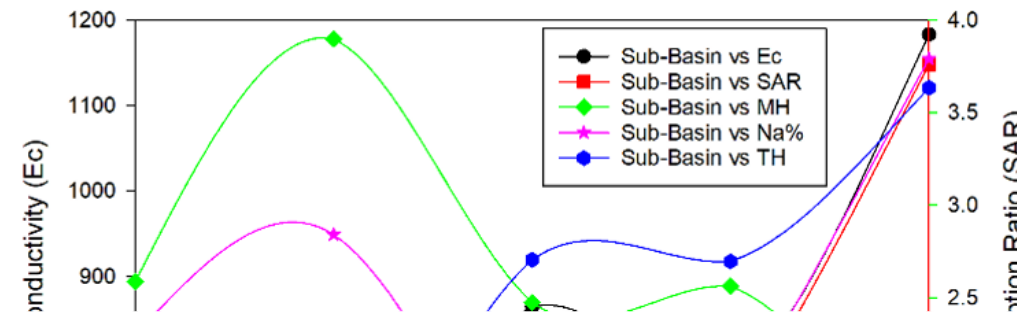

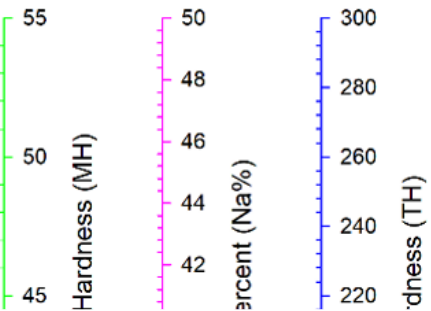

\section{Figure 4}

Plot showing sub-basin distribution of irrigation parameter 


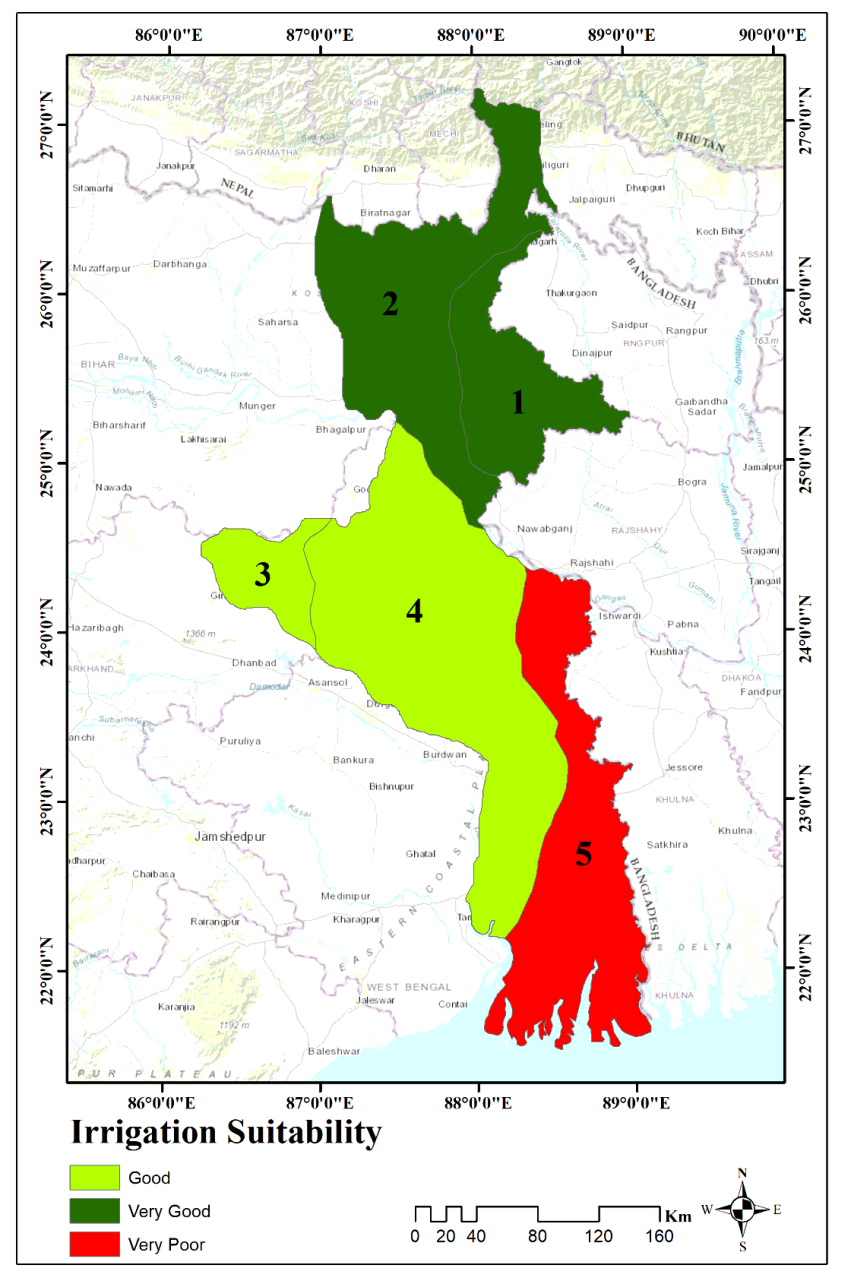

Figure 5

Geovisualization of irrigation suitability map in the Lower Ganga basin 


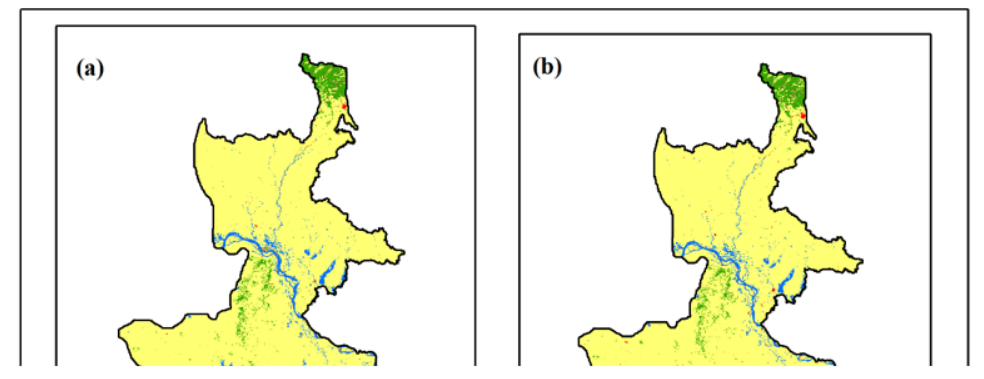

Figure 6

Spatiotemporal analysis land use dynamics (a) 2000 (b) 2005 (c) 2010 (d) 2015 


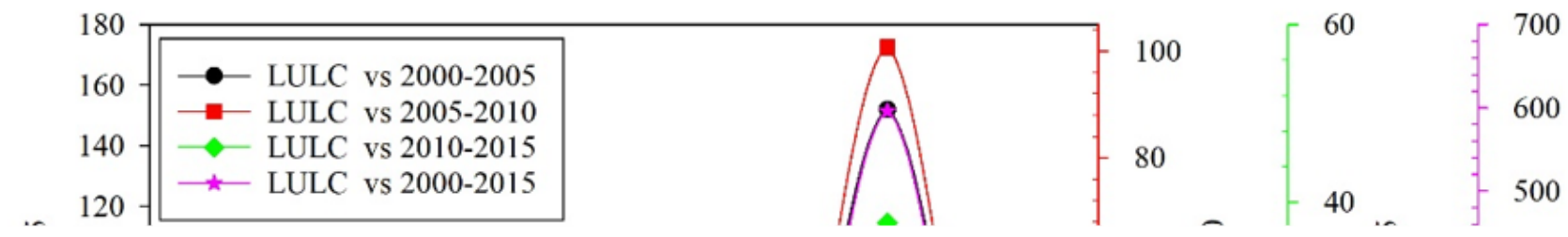

\section{Figure 7}

Plot showing spatiotemporal percentage change in land use and population-

(1) Agriculture (2) Forest (3) Grassland (4) Wetland (5) Settlement (6) Shrub land (7) Sparse Vegetation (8) Bare Area (9) Water (10) Population 